\title{
7. Dissecting Corporate Community Development in the Large-Scale Melanesian Mining Sector
}

\section{GLENN BANKS, DORA KUIR-AYIUS, DAVID KOMBAKO AND BILL F. SAGIR}

The chapter reports on an NZAID-funded project into corporate community development (CCD) initiatives at four Papua New Guinea (PNG) mine sites. ${ }^{1}$ The project was undertaken by a joint team of researchers from Massey University and the University of PNG. The study was framed to examine the motivations and attitudes of mining corporations to community development, to document the activities they carried out under the banner of CCD, to see what lessons had been learned in terms of both successes and failures, and to explore the nature of interactions between local, national and international stakeholders. Before reporting on these findings and implications, we set the broader context within which CCD initiatives occur.

1 NZAID has been reincorporated into the Ministry of Foreign Affairs and Trade as the New Zealand Aid Program. For reasons that should become obvious, we use the term 'corporate community development' as an alternative to the term 'corporate social responsibility', which is often preferred by industry (see Banks et al. 2016). 


\section{What Drives Corporate Community Development?}

A starting point is to consider the nature of the relationship between a multinational miner and the local community that is affected by it. Large-scale mining and its developmental effects are the subjects of both contention and ambiguity (Bebbington et al. 2008). The contradictions that mining poses, we believe, can be put down, in part at least, to an under-theorised approach to the nature of the relationship between these mining operations and affected communities. While there are a variety of ways of characterising this relationship (through the lens of power relations and agreements, human rights, or environmental impacts, among others) it is the economic flows from the mine that can be seen as central to shaping and driving this relationship through time. In the PNG context, these flows are shaped by the nature of the operation itself, as well as various sets of government regulations and pre-mining negotiations between the central stakeholders (including the community).

It is the compensation, wages, business contracts, royalties and equity dividends that are not only the inducements that entice communities to agree to mining developments on their land in the first place, but also drive the variety of processes that occur within communities around large-scale mines. Inward migration, one of the most destructive aspects of mining developments for local communities is, for instance, largely a consequence of people moving to the area seeking to access a share of some of the economic opportunities that the mine creates (see Chapter 11, this volume). Likewise, shifts to a cash economy, enhanced entrepreneurialism and individual ambition are all responses, through local cultural lenses, to the economic flows that spill out from the mining company. The social ills we associate with large-scale mining-gambling, prostitution, alcohol and violence-are not unconnected to these processes (Johnson 2011) (see Figure 7.1). 


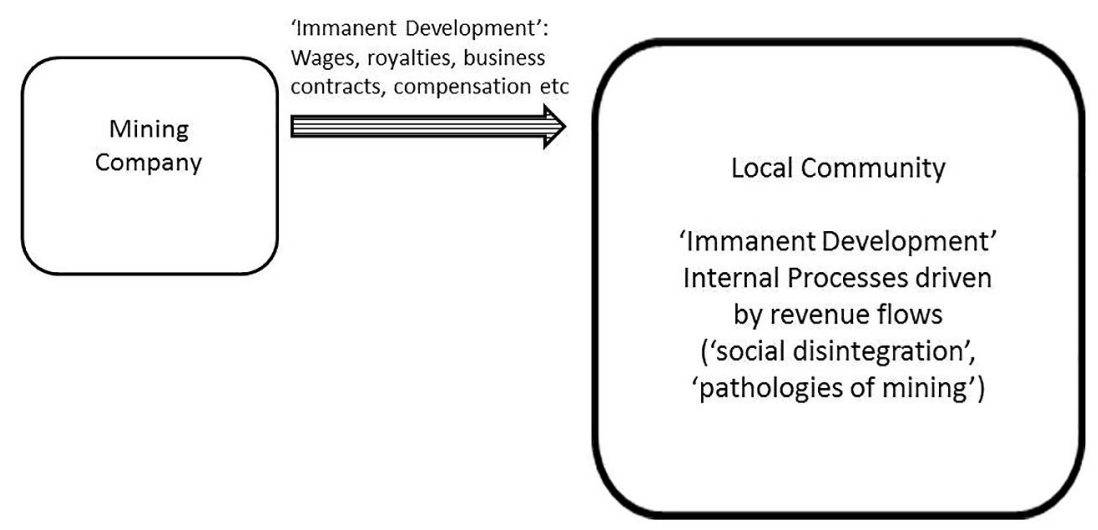

Figure 7.1 Mining and immanent development.

Source: Authors' diagram.

These internal processes can be regarded as what Cowen and Shenton (1996) describe as forms of 'immanent' development: inherent within community change, often unruly, typically energetic, always aspirational and frequently conflictual. Cowen and Shenton discuss these processes in the context of nineteenth-century European industrialisation and capitalism, describing how these broader forces recast the nature of European societies in ways that were often unpredictable and, in many cases, threatening to the established order. In the context of mining in Melanesia, terms such as 'social disintegration' (Filer 1990) or the 'pathologies' of mining (Golub 2006) are often used to characterise the rapid transformations that arise from the social effects of these mining operations on local communities. And despite many of these effects being seen as problematic by locals and observers, there is also a sense in which they are the sum of processes that people actively engage in to bring change to their lives and societies. There is an aspirational or progressive nature to much of what people are trying to do. We should also note here that these are precisely the sorts of social changes and processes that are regarded as raising social risks and threats to the mining operations themselves. The economic flows, then, drive processes that in turn are often regarded as a menace to the mining projects themselves, which are the sources of the flows. Significantly, though, when we talk of corporate social responsibility (CSR), it is clear that these immanent processes are not typically perceived as the sort of development space that resource companies can or should intervene in, or for which they should take any 
'social responsibility'. This is despite Colin Filer's (1990) argument that the extent, structure and nature of the economic flows from the mine are a primary influence on the speed and form of these 'immanent' processes.

One cautionary note in relation to the language used here is the degree of convergence and overlap between the oppositional categories just outlined: 'the mining company' and 'the local community' are not entirely distinct entities. At Porgera, a 2.5 per cent share of the equity in the joint venture is held by a local entity on behalf of the mining lease landowners, and 'local' employees make up more than two-thirds of the operational workforce of the company. Equity stakes have varied at other sites, but in all cases local employees make up the dominant component of the workforce. In other words, the 'local' is an element of the capital (albeit minor) and the labour (a much more significant share) of the company and, indeed, there is also overlap to an extent in the visions for local development that many in the community and company hold.

At least since the closure of Bougainville in 1989, and certainly in the context of discourses around compliance to CSR standards and codes of the past decade, mining companies have moved to engage more directly in community development efforts (see Imbun 1994, 2006). In part we can see that these CCD programs seek to reduce the risk posed to the operation by the immanent forms of development already discussed (see Figure 7.2).

These corporate initiatives fit neatly into what Cowen and Shenton (1996) characterise as 'intentional' forms of development interventions. They are usually driven by forces external to the communities, ${ }^{2}$ and are deliberate, strategic interventions into community processes. Cowen and Shenton's original concern was with the early form of religious and secular interventions during the industrial revolution that targeted those who had been marginalised by the 'immanent' development processes that capitalism and industrialism had sparked. They then applied this understanding to the contemporary aid and development landscape. What the authors highlighted was that these intentional forms of development are economically, socially and culturally conservative, and seek to essentially counter the unruly forms of change that immanent development creates. In what follows, we identify a range of corporative initiatives that fit this

2 Lihir is something of an exception to this rule (see Bainton 2010). 
notion of conservative forms of intentional development in corporate programs that promote governance, law and order, education, health and cultural heritage.

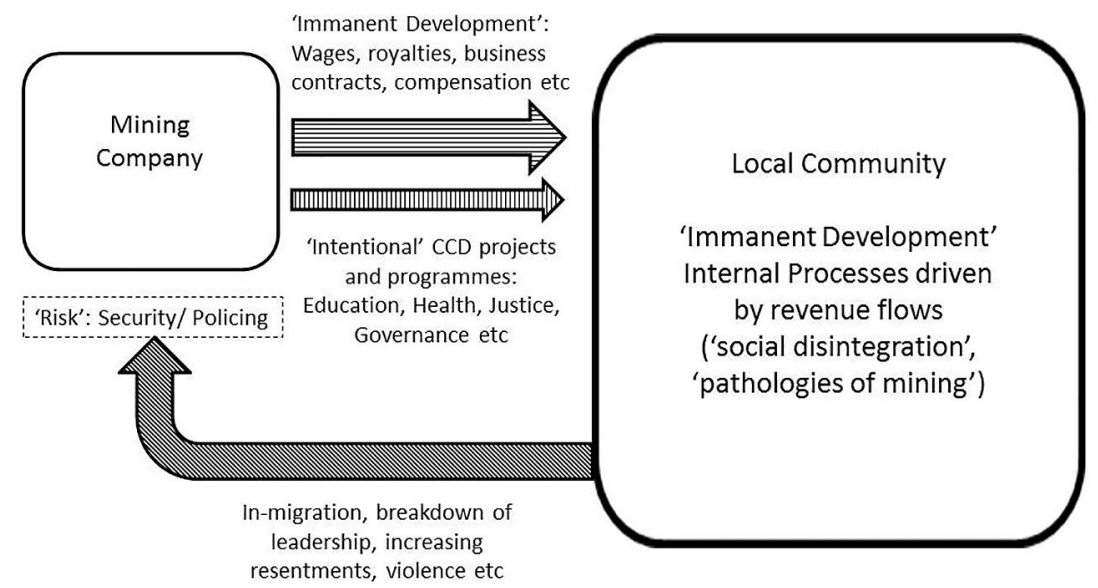

Figure 7.2 Mining, immanent and intentional forms of development.

Source: Authors' diagram.

There are two further points to be made in relation to the tensions between the immanent and the intentional. First, there is a constant tension between many of the 'intentional' projects and the 'immanent' processes they seek to counter. Corporate resource commitments to CCD are typically nowhere near as significant as what the community receives from the economic flows, and hence it is easy to identify cases where the intentional corporate development projects and schemes are undermined by, or remain marginal to, the broader immanent processes.

Second, drawing on the work of Ferguson (1990) and $\mathrm{Li}$ (2007) in relation to donor-funded development projects, we can also discern depoliticising tendencies at work in the intentional development work of CCD. The 'immanent' processes of community change are intensely political at local and higher levels, in part due to contests over the distribution of the revenue flows from the mine (see Burton 2014; Golub 2014). In contrast, the corporations tend to avoid becoming implicated in these political processes and, reflecting this, their intentional development programs have depoliticising tendencies: they seek to remain apolitical and focused on technical or material interventions, or what we can characterise as 
strengthening of infrastructure and institutions. Seeking an apolitical presence-depoliticising development-is itself, however, an intensely conservative political movement.

\section{The Project}

With this conceptual frame by way of backdrop, we now turn to report on a research project funded by NZAID, the New Zealand Government's aid and development agency, between 2009 and 2010. The project had two primary aims:

- to gain an understanding of the ways in which CCD programs reconciled tensions between community expectations and aspirations and corporate demands and constraints;

- to provide an initial investigation of the effectiveness of CCD programs at four mine sites in terms of broader measures of development effectiveness.

In broad terms, we were keen to gain and promote a greater understanding of CCD programs and use this to facilitate more integration between state, donor and corporate development initiatives. All four of us had previously worked in community development and/or the extractive sector in PNG, with both Sagir and Banks having long-standing research interests in the area, and the current project built on this existing body of research and knowledge. We visited four mine sites-Ramu and Porgera in June 2009, Lihir in February 2010, and Ok Tedi in October 2010-for periods of between three and seven days (see Figure 7.3). The sites were chosen in part to reflect the different geographical settings_-from insular Lihir to the huge area impacted by the Ok Tedi mine-and in part to reflect the length of time they had been operating —Ok Tedi since 1984, Porgera since 1991, Lihir since 1997, and Ramu, which was still halfway through construction during our visit.

At each site we interviewed management, community affairs staff and other company personnel involved in local community development, local government officials, and local representatives and organisations. We also collected and collated secondary data on community development at each site, and spoke to representatives of other national stakeholders, such as the PNG Chamber of Mines and Petroleum. 


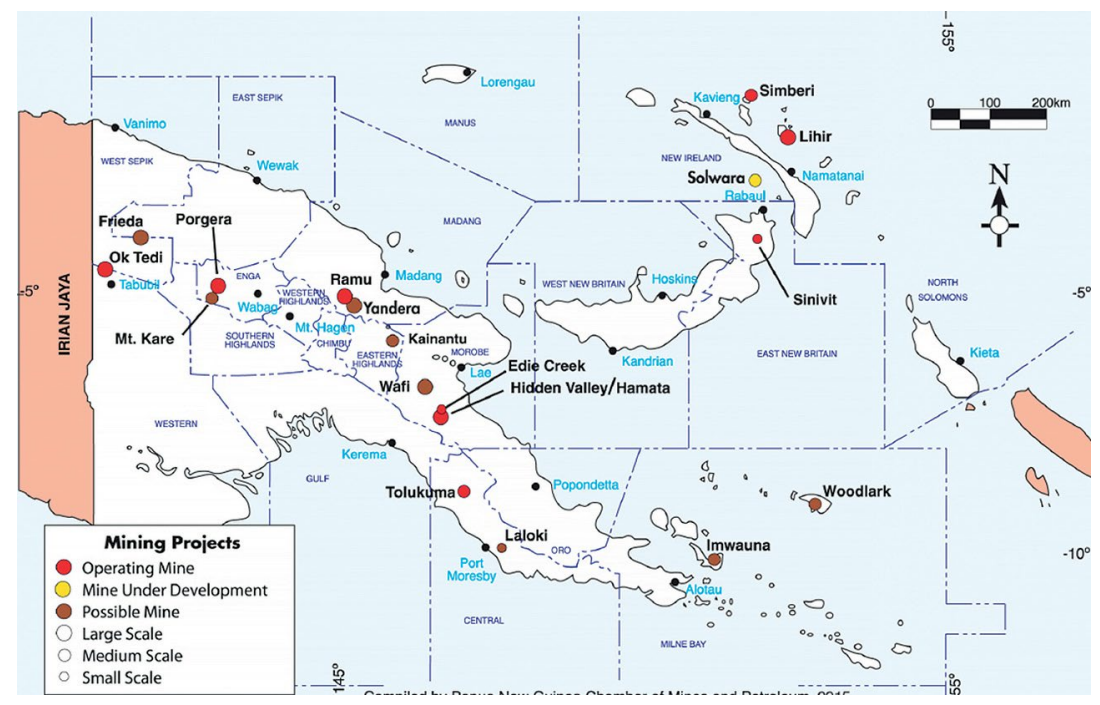

Figure 7.3 Papua New Guinea mining operations.

Source: PNG Chamber of Mines and Petroleum (pngchamberminpet.com.pg/mining-in-png/).

\section{Research Findings}

There is not scope here to provide even a brief overview of the CCD programs at each of the operations visited (see Banks et al. 2013 for more details). Instead, what follows is organised around five key themes that emerged from the research.

\section{Scale and Range of Programs}

First, it was clear that the scale and range of current CCD activities at each site made them very significant local drivers of development. Indeed, several were larger than the programs of most donor agencies operating in PNG. On Lihir, for example, the Lihir Sustainable Development Plan receives K32 million annually ${ }^{3}$ from Newcrest Mining to support Lihirian development activities that range from health and education initiatives to cultural heritage and housing and infrastructure work. This payment is not the only support that Newcrest provides, but it is the most substantial.

3 The amount is adjusted each year to reflect movements in the consumer price index. The revised integrated benefits package was originally worth K20 million per year over five years. 
In contrast, the Ok Tedi and Fly River Development Program Business Plan (OTFRDP 2010) outlined potential project funding sources worth up to K400 million.

The range of development activities undertaken by the companies was also notable, and included:

- law and order initiatives, particularly at Porgera (see BGC 2014);

- support for women's activities at Porgera, Ok Tedi and Lihir (see Chapter 10, this volume);

- various forms of support for local and provincial health services, especially at Lihir and Ok Tedi (see NFHSDP 2013);

- support for cultural heritage programs at Lihir (see Bainton et al. 2011);

- livelihood programs at Ramu, and to a lesser extent Ok Tedi and Porgera; and

- various forms of support for business development at all sites (see Johnson 2012; Bainton and Macintyre 2013).

While the list here is necessarily selective, all of these activities clearly align with the idea of this CCD support being targeted at conservative, apolitical initiatives: supporting law and order, women (and by implication traditional family structures), health, cultural heritage and small-scale (orderly) livelihood and business development. These forms of CCD thus fit neatly within Cowen and Shenton's model of 'intentional development'.

\section{Motivations}

There was a wide variety of motivations behind these various CCD initiatives. Indeed, different initiatives by the same mining company were typically carried out for a mix of different reasons, and even single programs or activities rarely had just one motivation. The motivations identified spanned a spectrum of 'voluntariness' that compounds the difficulty of discussing such activities as 'voluntary CSR' initiatives. We are able to identify and briefly sketch seven potential motivations for different types of activity. 
The least voluntary of these community development activities are what can be labelled negotiated obligations, where commitments are encoded in agreements: 'we do these because we have to-it is in the agreement'. At the next level are risk management activities: 'we do these things to keep our operations safe'. The Restoring Justice Initiative developed by Barrick Gold in association with local district administration, provincial and national governments, and community stakeholders is a clear example of this form of community development (BGC 2014).

Less directly tied to operational safety are initiatives that can be seen to be linked to the idea of the social licence to operate (Owen and Kemp 2013): 'if we don't do these things the community will become frustrated and can pose a threat to the operation'. At times, this motivation can also stretch to individuals or groups within the community: the need to appease specific groups and individuals who can affect the operation arises regularly, and companies (sometimes unwillingly) feel obligated to meet these demands. It is often these focused initiatives targeted at certain groups that draw the ire of other locals who do not receive the same treatment.

These initiatives are closely aligned with, but distinctly different from, what can be more directly seen as CSR-driven initiatives. To varying degrees the multinational miners bring weighty global charters and lofty community-focused corporate rhetoric to their local programs. The Barrick response to the Human Rights Watch investigations into rape and sexual harassment by mine security personnel (HRW 2011), while rightly focused on seeking ways to reduce violence against women at Porgera, can be seen as an example, with the various initiatives seemingly tied more to global rhetoric and practices than local conditions and realities (see Burton 2014). Indeed, it appears to us that the differences between the 'social licence to operate' and CSR initiatives boil down to the degree to which they reflect local conditions as opposed to global corporate fixations.

In some cases, and in line with much of the critical literature on CSR and mining, the public relations value of some community development programs was certainly identified by both corporate and external interviewees as being of importance. The glossy photo for corporate sustainability reports and websites was a factor that provided a motivation for the corporate support for some programs, in part at least because it could be used to try to negate negative criticism of their presence by other (usually international) groups such as non-governmental organisations. Rarely, though, was it the sole or even primary motivation for activities or programs. 
Also discernible was a strong element of altruism behind some corporate initiatives. Most of the 'community development' sections of the companies were staffed and managed by people with experience in, and commitment to, community development. These people often want to do the right thing by the community and empathised with local people's situation: at least one operation used the slogan 'leaving behind a better future' for its CCD strategy. There is, then, a 'will to improve' (Li 2007), even if this does not always translate into sustainable forms of development. Critics-both local and external-appear to overlook the extent to which staff in these sections are genuinely trying to bring about positive change for the affected communities, working within contexts that are not always conducive to this outcome.

Finally, in terms of motivation, business development assistance is an example of CCD initiatives that can have a relatively direct economic payoff for the companies involved. These activities can certainly lead to reduced contracting and operating costs, given that local contractors are likely to be significantly cheaper than national or international companies. Hence there can be an economic motivation behind some initiatives, although, like public relations, this was not the sole or primary motivation for any of the activities we identified.

What we can see, then, in terms of these 'intentional' development activities is a variety of motivations, some of which are clearly 'defensive' and some deliberately depoliticising and socially conservative (see Table 7.1). As previously noted, within any single program or activity there is often a degree of overlap between these categories - they are certainly not mutually exclusive. It is also worth pointing out two further points related to motivations.

First, in some senses, motivations matter less than outcomes, and there clearly are some CCD projects that, even if designed with strong elements of self-interest in mind, have delivered benefits to elements of some communities. There is also the view, among some of the corporate actors, that self-interested and self-managed corporate programs are more likely to be completed, and hence to deliver 'outcomes', than those that rely on government or local parties for their implementation. Sometimes such outcomes are additional to what was planned, and sometimes they are completely unintended but, regardless, these opportunities and improvements in livelihoods for individuals, and sometimes whole communities, have been significant at different points in time. 
Second, and by way of contrast, there is good evidence from the world of development that undertaking activities with a mix of motives (e.g. self-interest and poverty reduction) is likely to be less effective than having programs with singular and clear motivations. Undertaking community development projects with the aim of achieving multiple goals (e.g. community development and risk reduction) is unlikely to be effective in achieving any one goal.

Table 7.1 A typology of motivations for corporate community development activities.

\begin{tabular}{|c|l|l|}
\hline $\begin{array}{c}\text { Degree of } \\
\text { 'voluntariness' }\end{array}$ & Motivation & Rationale and examples \\
\hline \multirow{2}{*}{ LOW } & Negotiated responsibility & $\begin{array}{l}\text { 'It's in the agreement: we are required } \\
\text { to do it' (compensation and royalty } \\
\text { flows, resettlement programs, specified } \\
\text { infrastructure) }\end{array}$ \\
\cline { 2 - 3 } & Risk management & $\begin{array}{l}\text { 'If we don't do it, we will get closed } \\
\text { down' (restoring justice) }\end{array}$ \\
\cline { 2 - 3 } & Social licence to operate & $\begin{array}{l}\text { 'If we want to maintain community } \\
\text { support, we need to do this' } \\
\text { (water tanks) }\end{array}$ \\
\cline { 2 - 3 } & $\begin{array}{l}\text { Corporate social } \\
\text { responsibility }\end{array}$ & $\begin{array}{l}\text { 'If we want to maintain business } \\
\text { reputation and international image, we } \\
\text { need to do this' (HIV/AIDS) }\end{array}$ \\
\cline { 2 - 3 } & Public relations & $\begin{array}{l}\text { 'Looks good on our flashy brochures' } \\
\text { (some footbridges, aid posts, } \\
\text { schools, etc.) }\end{array}$ \\
\cline { 2 - 3 } & 'The will to improve' & $\begin{array}{l}\text { 'Leaving behind a better future' } \\
\text { (livelihood programs, women's groups) }\end{array}$ \\
\cline { 2 - 4 } & Direct business case & $\begin{array}{l}\text { Cost reduction (business development, } \\
\text { local training and education) }\end{array}$ \\
\hline
\end{tabular}

Source: Banks et al. 2013.

\section{Organisational Structure}

The research highlighted a wide diversity of organisational structures adopted to plan and deliver these CCD activities. There is clearly no one model of how corporations can or should deliver community development programs. As with the motivations behind their different initiatives, corporations utilise a variety of mechanisms for this purpose.

At one end sits the Lihir Sustainable Development Plan (LSDP). As previously noted, this program is funded directly by Newcrest, but in many senses it operates at arm's length from the company. The LSDP 
is the outcome of the second formal round of negotiations between the Lihir community and mine's operator, although the negotiations were concluded before Newcrest took over the operation, after the first round had resulted in a more standard set of agreements bundled together as an 'integrated benefits package'. ${ }^{4}$ Much of the design of the LSDP, and perhaps more importantly its vision for community development, has come from the Lihir Mine Area Landowners Association (LMALA). ${ }^{5}$ And despite the problem of 'elite capture'-the binding of local elites to corporate interests-the LSDP represents an all-encompassing, locally driven, designed and delivered community 'development' agency that leaves most donor programs far behind in terms of local 'ownership' of development.

Ok Tedi has a long (30-year) history of various development projects and initiatives. The present iteration is relatively recent and complex, in part a legacy of previous agreements and arrangements, as well as more recent initiatives that were envisaged to last beyond the current mine life (see Chapter 8, this volume). At the core sits the new Ok Tedi and Fly River Development Program (OTFRDP), which is gradually assuming a greater proportion of the previous community development roles performed by Ok Tedi Mining Ltd (OTML), and aims to increase its independence from OTML over the next few years. The structure is designed externally, but is now working closely with communities up and down the extensive $\mathrm{Ok}$ Tedi Fly River system to be able to respond better to community needs. The relationship between OTFRDP and other stakeholders, including the local and provincial governments, as well as the mine's operator, is still being developed, especially through the implementation of 'mine continuation agreements with local communities', but the intention is that OTFRDP should become the primary mechanism for delivering community development in Western Province by the time the mine finally closes. ${ }^{6}$

\footnotetext{
4 With some additions to the 'standard package', including having the mine's environmental plan included in the agreement. The third version of these agreements was still being negotiated in 2016. 5 Nick Bainton (personal communication, November 2015) has correctly noted that while the LSDP was largely conceived and written by LMALA, it contains an integrated vision for the development of the island with reference to consolidated local development budgets and multistakeholder management structures.

6 Organisational relationships were complicated by the nationalisation of the PNG Sustainable Development Program Ltd in 2013 (see Chapter 8, this volume).
} 
At Porgera, CCD projects and programs have been much more centrally, perhaps conventionally, controlled and directed by the operator's community development department. ${ }^{7}$ This has meant that the Porgera Joint Venture has been able to respond more rapidly to threats and opportunities that have arisen in its relationship with local communities, but it has lacked a clear systematic vision and consistent long-term approach to community development. In this sense, there is less independence from short-term, on-site and corporate head office decision-making, and the company's CCD efforts certainly have less of a community-driven flavour when compared to those at Lihir.

The nature of these different institutional arrangements is dependent on a range of factors, such as the various negotiated agreements that have specified particular systems and structures (as at Lihir and Ok Tedi), the history of company-community relationships (as at Porgera) and a mix of corporate, management and local decisions. The situation at the Ramu project, for example, shifted away from an emphasis on the Ramu Nickel Foundation with the arrival of the China Metallurgical Group Corporation as the project's developer. The geographical and cultural context also influences the type and scale of delivery mechanism that is used. The difference between Ok Tedi, with its huge riverine footprint, fragmented and culturally diverse population, and the small contained island environment at Lihir, where the local population has a cultural predisposition to visionary planning, is in part responsible for the very different approaches that have been adopted.

\section{Sustainable Successes Hard to Find}

One of the striking features of our survey was the limited number of successful sustainable initiatives that could be identified. Ok Tedi has been operating for more than 30 years, Porgera for more than 20 years, and Lihir since 1997. All, as we have seen above, have committed substantial sums to 'community development' in various guises over this time. And yet there were a limited number of 'successes' that could be pointed to in terms of corporate initiatives. Certainly a lot of new activities and programs had been developed in recent years, but far fewer longer-term projects were regarded by stakeholders as having made a difference to

7 The title of this agency has changed several times during the life of the project. 
community development. ${ }^{8}$ This was reflected in the impression one of the newer members of our team had that 'the companies were only starting community development work in the last couple of years'.

In large part this can be linked to the argument that these 'intentional' corporate development initiatives are responding to, and occur within, a context of the much broader 'immanent' social and economic trends within the surrounding communities. In other words, despite their size and resources, the companies have limited ability (or will) to shape the longer-term trajectory of community social and economic change around their operations. There is also the issue of an almost complete absence of long-term data against which community change, and the effects of corporate activities, can be tracked-a point to which we shall return.

Some projects and activities have clearly had significant outcomes for the affected communities. The ones that are discussed now are projects that in 2009-10 were regarded as having been beneficial to the communities over a longer time period. The Porgera District Women's Association is an institution that with ongoing corporate support has had a significant presence and impact for women at Porgera over a 20 -year period. It has coordinated awareness campaigns for women, supported a microcredit scheme, and provided assistance with various livelihood activities (dressmaking and chicken farming, for example). At Lihir and Ok Tedi, there are long-standing health programs and facilities that have been highly effective in terms of health outcomes (Hemer 2005; Bentley 2011; Thomason and Hancock 2011). In economic terms, company assistance with 'landowner umbrella companies' has typically had a chequered path, but at Ok Tedi (Star Mountain Investment Holdings), Lihir (Anitua and its subsidiary, National Catering Services) and Porgera (Ipili Porgera Investments), some landowner companies have developed into major national companies with multimillion dollar businesses (Jackson 2015). These companies have the potential to be major diversified economic assets for the local communities in the post-mine environment, and represent a significant contribution to long-term development that was achieved with the active support of the mining companies involved.

8 This may also be a function of a shift from social impact monitoring to reporting, a point for which we thank Nick Bainton. 
We were able to identify a number of instances where the resource company had provided support (mostly logistical) to government or donor projects, particularly health interventions. The Porgera Joint Venture (PJV), for example, had supported at least two Asian Development Bank health initiatives, including most recently an HIV/AIDs program at Porgera, building on studies by the PNG Institute of Medical Research that the PJV had also supported. Such collaboration is seen as particularly beneficial as it combines the developmental focus of the donor with the resources and logistics of the companies involved.

The relationship between the mining companies and the local and provincial governments in and around their operations had varied significantly through time and by location. There were situations where the developmental efforts of the company were closely linked with those of the district administrations and local-level governments, although the latter were usually highly politicised and of limited effectiveness in each of the locations. There were also cases, such as Porgera and Ok Tedi, where a number of attempts, largely funded and driven by the company, were made to develop a district planning framework, yet there was very little effective coordination in delivering development to communities. There was a tension here, though, with the widely observed 'retreat of the state' from these resource enclaves (see Filer 1997). This was partly driven by the pressure on companies to act as a 'pseudo-government' (see Chapter 8, this volume), partly by the huge apparent disparity in resources, capacity and effectiveness between company and local government, yet partly by the desire for companies to work more closely with local actors, including government actors. This latter trend, a reflection of best practice in the aid and development arena, is made more difficult where local government is barely present in the vicinity of the mine sites. This reflects broader concerns with the ways in which governmentality is constructed and practiced in relation to resource extraction (Ferguson 2005; Le Meur et al. 2013).

\section{Corporations are Not Donors}

The final issue we discuss here is the difference between these CCD activities and those of bilateral and multilateral donors. It is worth stressing the obvious and stating, as much of the critical literature on CSR does, that these mining companies are not bilateral development donors, and indeed their primary motivation is profit, not community 
development. Within this context, and to a large extent reflecting the range of motivations identified earlier, we can identify some significant differences between the community development activities of donors and those of these four mining operations.

The first is that community participation in the identification, design and implementation of CCD programs is often limited. While best practice development planning would involve a participatory approach from the start, and would be influenced by notions of development as empowerment, with a focus on building capacity and skills within the target community, the mining companies give little systematic attention to such approaches. Apart from a number of the key projects already identified, such as those at Lihir, very little of this was evident in terms of the practice of these CCD initiatives.

In part, this could be put down to the context within which these CCD programs operated. A significant element of this was the high degree of dependence on the mining company exhibited by local communities, which limits commitment by the community, and ultimately the company, to these community development projects. There is often limited broad-based community support for many of the initiatives because they are often not seen as being driven by local priorities. These priorities are typically dominated by the effects of the highly politically charged nature of the immanent development processes, including in-migration, landownership, representation and identity. This apathy and dependency is a trait frequently maligned by external observers: the lazy, greedy resource owner or landowner is a common stereotype within PNG. However, from the local perspective, given the obvious power, wealth and resource imbalances that exist between the corporation, the state and the local community, a range of culturally derived positions on dependency and reciprocity could be anticipated. Although these are now recognised in the development literature (see Mawdsley 2012), they are probably poorly understood and rarely dealt with by corporate actors.

In terms of other differences from donor development programs, there was an almost total absence of systematic monitoring and evaluation for these corporate programs. This is in contrast to the development industry, for which monitoring and evaluation are central to contemporary practice, and for which there is a specialised branch of the industry. Here we can identify the lack of clear accountability as a factor: lines of accountability for these programs remain closely tied to internal corporate systems rather 
than reflecting a notion of programs and projects being accountable to the recipient communities, as current aid practice at least normatively preaches. We see this as being important in terms of the success of these corporate programs, since without clear monitoring and evaluation of results—and tying this into institutional learning regarding what makes for successful development - there is little requirement for these programs to be accountable beyond the banal corporate financial accounting for all expenditures. CSR expectations today ensure that the corporations continue to expend resources on their community development sections regardless of their developmental outcomes, underlining the mix of corporate motivations noted earlier. What we do know from the literature is that mixed motivations for bilateral aid—classically trying to mix strategic and developmental objectives-reduces the effectiveness and sustainability of these efforts, and can even further undermine the development of the recipient. Our review here suggests the danger of the same poor outcomes arising from CCD programs that try to achieve a mix of objectives—risk management, development, meeting CSR obligations, and so forth.

\section{Conclusions}

Large-scale multinational mining projects are long-term ventures, typically lasting more than 20 years, in contrast to the generally much shorter time horizon of bilateral and multilateral donors. As a result, CCD programs have the potential to provide long-term development assistance to surrounding communities (UNDP 2014). What we have shown here is that these CCD efforts vary across the PNG mining operations, but all are a significant presence for local communities, and sometimes, as in the case of Ok Tedi, much more broadly (see Chapter 8, this volume). Unfortunately, the results of these efforts have typically been piecemeal, and successful sustainable activities are relatively rare. We hope that our review here can provide the start of a discussion about why this is the case.

We would argue that untangling the motivation for CCD programs is likely to improve their effectiveness (see GoA 1997). Mixing motives that include external CSR concerns with risk management, social licence and a desire for 'real' development is always going to lead to contradictions and compromised outcomes. 
It is also clear that there was potential for substantial learning and greater cooperation across sectors. The corporations have carried out various forms of community development for decades, tried a variety of formats and approaches, and had a range of successes and failures. They have, as noted earlier, resources and a logistical capacity that is unrivalled in remote parts of the country. At the same time, it is clear from our review that there are elements of current development practice, such as monitoring and evaluation and designing effective participatory approaches, that could be of considerable benefit to the companies and, by implication, the recipient communities. More attention to these 'front-end' and 'backend' aspects of projects and programs does mean both loosening up control over the design and subsequent direction of the programs, and being more open, transparent and accountable for the failures as well as the successes of these initiatives.

Finally, in terms of the schematic model that was posed at the start of this chapter, there is a need for more attention to the linking and integration of the CCD programs with the financial flows that the mining operations engender. The 'intentional development' of these corporate initiatives and programs occurs within the context of, and is often undermined by, the much broader and rapid 'immanent development' processes that are initiated by these financial flows. Indeed, in many respects CCD is, from the community viewpoint, peripheral to the 'main game': the negotiations and conflicts around the distribution of the economic flows from the operations. We would argue that this will remain the case until companies and communities are able to link these flows to participatory development activities that seek to address, in a positive way, the major 'immanent' shifts and transformations in the communities that are driven by these same financial flows. This may involve corporations being more interventionist in terms of the realm of local politics, for example by negotiating more integrated benefit sharing and community development programs. But failure to do so means not only abdicating responsibility for the 'immanent development' that their economic presence drives; it will also continue to mean that their CCD efforts will produce few sustainable, beneficial development outcomes for affected communities. 


\section{References}

Bainton, N.A., 2010. Lihir Destiny: Cultural Responses to Mining in Melanesia. Canberra: ANU E Press.

Bainton, N.A., C. Ballard, K. Gillespie and N. Hall, 2011. 'Stepping Stones across the Lihir Islands: Developing Cultural Heritage Management Strategies in the Context of a Gold-Mining Operation.' International Journal of Cultural Property 18: 81-110. doi.org/10.1017/ S0940739111000087

Bainton, N.A. and M. Macintyre, 2013. "'My Land, My Work”: Business Development and Large-Scale Mining in Papua New Guinea.' In F. McCormack and K. Barclay (eds), Engaging with Capitalism: Cases from Oceania. Bingley (UK): Emerald Group Publishing (Research in Economic Anthropology 33). doi.org/10.1108/s01901281(2013)0000033008

Banks, G., D. Kuir-Ayius, D. Kombako and B. Sagir, 2013. 'Conceptualizing Mining Impacts, Livelihoods and Corporate Community Development in Melanesia.' Community Development Journal 48: 484-500. doi.org/10.1093/cdj/bst025

Banks, G., R. Scheyvens, S. McLennan and A. Bebbington, 2016. 'Conceptualising Corporate Community Development.' Third World Quarterly 37: 245-263. doi.org/10.1080/01436597.2015.1111135

Bebbington, A., L. Hinojosa, D.H. Bebbington, M.L. Burneo and X. Warnaars, 2008. 'Contention and Ambiguity: Mining and the Possibilities of Development.' Development and Change 39: 887-914. doi.org/10.1111/j.1467-7660.2008.00517.x

Bentley, K., 2011. Lihir Social Demographic Health Survey. Canberra: Centre for Environmental Health.

BGC (Barrick Gold Corporation), 2014. 'Neighborhood Watch: How the Restoring Justice Initiative Addresses Law and Order Challenges in the Porgera District.' Viewed 4 April 2017 at: barrickbeyondborders. com/people/2014/11/neighborhood-watch-how-the-restoring-justice -initiative-addresses-law-and-order-challenges-in-the-porgera-district/ \#.VIECMdKUfzg 
Burton, J., 2014. 'Agency and the "Avatar" Narrative at the Porgera Gold Mine, Papua New Guinea.' Journal de la Société des Océanistes 138-139: 37-51. doi.org/10.4000/jso.7118

Cowen, M. and R. Shenton, 1996. Doctrines of Development. London: Routledge. doi.org/10.4324/9780203392607

Ferguson, J., 1990. The Anti-Politics Machine: 'Development', Depoliticization, and Bureaucratic Power in Lesotho. Cambridge: Cambridge University Press.

_ 2005 . 'Seeing Like an Oil Company: Space, Security and Global Capital in Neoliberal Africa.' American Anthropologist 107: 377-382. doi.org/10.1525/aa.2005.107.3.377

Filer, C., 1990. 'The Bougainville Rebellion, the Mining Industry and the Process of Social Disintegration in Papua New Guinea.' Canberra Anthropology 13(1): 1-39. doi.org/10.1080/03149099009508487

1997. 'The Melanesian Way of Menacing the Mining Industry.' In B. Burt and C. Clerk (eds), Environment and Development in the Pacific Islands. Canberra: The Australian National University, National Centre for Development Studies (Pacific Policy Paper 25).

GoA (Government of Australia), Committee to Review the Australian Overseas Aid Program, 1997. One Clear Objective: Poverty Reduction through Sustainable Development. Canberra: Committee to Review the Australian Overseas Aid Program ('the Simons Report').

Golub, A., 2006. Making the Ipili Feasible: Imagining Local and Global Actors at the Porgera Gold Mine, Enga Province, Papua New Guinea. University of Chicago ( $\mathrm{PhD}$ thesis).

— 2014. Leviathans at the Gold Mine: Creating Indigenous and Corporate Actors in Papua New Guinea. Durham (NC): Duke University Press.

Hemer, S., 2005. 'Health Care and Illness in Lihir, New Ireland Province, in the Context of the Development of the Lihir Gold Mine.' PNG Medical Journal 48(3-4): 188-195.

HRW (Human Rights Watch), 2011. 'Gold's Costly Dividend: Human Rights Impacts of Papua New Guinea's Porgera Gold Mine.' Viewed 4 April 2017 at: www.hrw.org/en/reports/2011/02/01/gold-s-costlydividend 
Imbun, B.Y., 1994. 'Who Said Mining Companies Take and Do Not Give? The Mining Companies' Role of Social Responsibility in Papua New Guinea.' TaimLain: A Journal of Contemporary Melanesian Studies 2(1): $27-42$.

__ 2006. 'Cannot Manage without the "Significant Other": Mining, Corporate Social Responsibility and Local Communities in Papua New Guinea.' Journal of Business Ethics 73: 177-192.

Jackson, R.T., 2015. The Development and Current State of Landowner Businesses Associated with Resource Projects in Papua New Guinea. Port Moresby: PNG Chamber of Mines and Petroleum.

Johnson, P., 2011. 'Scoping Project: Social Impact of the Mining Project on Women in the Porgera Area.' Port Moresby: Porgera Environmental Awareness Committee.

—_, 2012. Lode Shedding: A Case Study of the Economic Benefits to the Landowners, the Provincial Government and the State, from the Porgera Gold Mine: Background and Financial Flows from the Mine. Port Moresby: National Research Institute (Discussion Paper 124).

Le Meur, P.-Y., C. Ballard, G.A. Banks and J.-M. Sourisseau, 2013. 'Two Islands, Four States: Comparing Resource Governance Regimes in the Southwest Pacific.' In J. Wiertz (ed.), Proceedings of the 2nd International Conference on Social Responsibility in Mining. Santiago: Gecamin Digital Publications.

Li, T.M., 2007. The Will to Improve: Governmentality, Development, and the Practice of Politics. Durham (NC): Duke University Press. doi.org/ $10.1215 / 9780822389781$

Mawdsley, E., 2012. 'The Changing Geographies of Foreign Aid and Development Cooperation: Contributions from Gift Theory.' Transactions of the Institute of British Geographers 37: 256-272. doi.org/10.1111/j.1475-5661.2011.00467.x

NFHSDP (North Fly Health Services Development Program), 2013. 2011 Annual Report. Tabubil (PNG): NFHSDP.

OTFRDP (Ok Tedi and Fly River Development Program), 2010. Business Plan. Tabubil: OTFRDP. 
Owen, J.R. and D. Kemp, 2013. 'Social Licence and Mining: A Critical Perspective.' Resources Policy 38: 29-35. doi.org/10.1016/j. resourpol.2012.06.016

Thomason, J. and M. Hancock, 2011. PNG Mineral Boom: Harnessing the Extractive Sector to Deliver Better Health Outcomes. Canberra: The Australian National University, Development Policy Centre (Discussion Paper 2).

UNDP (United Nations Development Programme), 2014. 2014 National Human Development Report, Papua New Guinea. From Wealth to Wellbeing: Translating Resource Revenues into Sustainable Human Development. Port Moresby: UNDP and Department of National Planning and Monitoring. 
This text is taken from Large-scale Mines and Local-level Politics: Between New Caledonia and Papua New Guinea, edited by Colin Filer and Pierre-Yves Le Meur, published 2017 by ANU Press, The Australian National University, Canberra, Australia. 